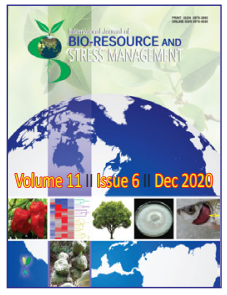

\title{
Export Oriented Agriculture in the Agri-History of India
}

\author{
Rajendra Prasad and Yashbir Singh Shivay*
}

Division of Agronomy, ICAR-Indian Agricultural Research Institute, New Delhi (110 012), India

f

Corresponding Author

Yashbir Singh Shivay

e-mail: ysshivay@hotmail.com

Citation: Prasad and Shivay, 2020. Export Oriented Agriculture in the Agri-History of India. International Journal of Bio-resource and Stress Management 2020, 11(6), i-v. HTTPS://DOI.ORG/10.23910/1.2020.2141a

Copyright: (c) 2020 Prasad and Shivay. This is an open access article that permits unrestricted use, distribution and reproduction in any medium after the author(s) and source are credited.

Data Availability Statement: Legal restrictions are imposed on the public sharing of raw data. However, authors have full right to transfer or share the data in raw form upon request subject to either meeting the conditions of the original consents and the original research study. Further, access of data needs to meet whether the user complies with the ethical and legal obligations as data controllers to allow for secondary use of the data outside of the original study.

Conflict of interests: The authors have declared that no conflict of interest exists.

Article History

RECEIVED in $27^{\text {th }}$ July 2020 RECEIVED in revised form $26^{\text {th }}$ November 2020 ACCEPTED in final form $01^{\text {st }}$ December 2020

\begin{abstract}
India's agricultural research has the main emphasis on food grains production and rightly so because of short food supply and dependence on import of wheat from USA. Now the country has become self-sufficient in food and its research needs re-orientation because, most farmers remain below poverty line. Some attention was paid to traditional commercial crops such as cotton, sugarcane and potato for raising the level of farmers above poverty lines, but when they had surplus in production of these crops, they could not export these, because it was difficult to compete in the international market. Nevertheless, there are some herbal crops, where it can compete fairly well in the international export. For example, it has global monopoly in isabgol / psyllium and is topmost exporter in turmeric and only next to China in ginger. However, to maintain these positions in herbal crops in the international export market, India needs to invest a little more in agricultural, scientific and marketing research. Agricultural research is needed to develop high yielding varieties and their agronomy with higher content of main active chemicals and of course market research for new countries to export. Government of India needs to identify more such crops, the areas where they are grown and provide necessary research, processing facilities and procurement at pre-fixed price to facilitate their production and export. This will bring home the much needed foreign exchange and certainly raise the status of some farmers above the poverty line.
\end{abstract}

Keywords: Active chemicals, export, ginger, gingerol, isabgol, senna, turmeric

\section{Introduction}

Food has always been in short supply in India and several famines have occurred in India in the past (Bhatia, 1985). To mention a few, these include famines in the $1^{\text {st }}$ century during Gupta period in north India (Drèze, 1988) and during Ashoka period in Orissa (Keay, 2001); famines in Tamil Nadu during $13^{\text {th }}$ to $14^{\text {th }}$ century (Currey and Hugo, 1984; Walsh, 2006); famines in the Deccan, Maharashtra and Gujarat during $15^{\text {th }}$ to $17^{\text {th }}$ century (Walsh, 2006; Attwood, 2005). A 12-year drought and famine is mentioned in Mahabharata (Roy, 1889). Therefore, after gaining independence in 1947, the emphasis of agricultural research has been on increasing the production of foodgrains in the country and to great extent they have succeeded in this by introducing high yielding dwarf/semi-dwarf varieties of wheat (Swaminathan, 2013) and rice (Siddiq et al., 2012) and hybrids and composites of maize, sorghum and pearl millet (Kaul et al., 2010; Kumara Charyulu et al., 2011). India's agricultural research has thus centered for meeting dal-roti/chawal needs of the people and very little 
beyond it. Agricultural research in India is conducted by the Institutes under the umbrella of Indian Council of Agricultural Research which comes under Ministry of Agriculture, Cooperation and Farmers Welfare, while the responsibility of agricultural food procurement and distribution is under the Ministry of Food, which is done through Public Distribution System having ration shops throughout the country, certainly a Herculean task and the ministry has done it wonderfully well.

However, high yielding varieties of cereals demanded more inputs, such as better quality seeds, fertilizer and other agrochemicals and the farmers had to take loans from the banks, which many a time they were not able to return timely and many committed suicides (Das, 2011). This brings to the point that one has to think of net profit (preferably foreign exchange) from the farm field and not only the production, which has been the focus of attention of the Government of India and this brings the need for attention to the commercial crops other than the traditional commercial crops of sugarcane, potatoes and cotton etc. As a matter of fact, there have been more suicides, in cotton growing farmers than in those growing cereal crops (Dongre and Desmukh, 2012). Ministry of Food \& Agriculture (MOFA), Government of India (GOI) now needs to add a department of Export Oriented Agricultural to recognize the crops that can be exported. They need to demarcate the areas where they can be successfully grown and to initiate research for improving yield and quality of these crops as well as to explore new markets for these crops. Although Agricultural Product Export Development Authority (APEDA) is doing its job fairly well on the marketing front, research aspect is missing and it has to be MOA\&FW, GOIs responsibility. This paper draws attention to lesser known four commercial crops, namely, 1) Isabgol, in which India has the monopoly in the world market, 2) Turmeric (haldi), where India is number one in the export market, 3) Ginger, where India is next to China in the world export trade and 4) Senna, where again it has a sizeable share in the export market. These crops have not received the attention as they deserve. India has to seriously look into necessary advancements to maintain at least the present position in the export market. A brief discussion of these crops follows for the readers' information.

\section{Turmeric}

Turmeric (Curcuma longa) was domesticated in Southeast Asia, most probably in India, which has the greatest diversity of Curcuma species; around 40 to 45 species, while Thailand has about 30 to 40 species. Other countries in tropical Asia also have numerous wild species of Curcuma. The name of the genus, Curcuma, is derived from the Sanskrit kunkuma, referring to turmeric, used in India since ancient times. India is by far the largest producer and exporter of turmeric in the world. Andhra Pradesh, Tamil Nadu, Odisha, Karnataka, West Bengal, Gujarat, Meghalaya, Maharashtra, Assam are some of the important states growing turmeric, of which, Andhra Pradesh alone occupies $35.0 \%$ of the area and contributes about $47.0 \%$ of the country's production.

Turmeric can be grown in diverse tropical conditions from sea level to $1500 \mathrm{~m}$ above sea level, at a temperature range of $20-35^{\circ} \mathrm{C}$ with an annual rainfall of $1500 \mathrm{~mm}$ or more, under rainfed or irrigated conditions. Though it can be grown on different types of soils, it thrives best in well-drained sandy loam or loam soils with a $\mathrm{pH}$ range of 4.5-7.5 with good organic matter content.

Turmeric occupies about $6 \%$ of the total area under spices and condiments in India. In 2018, India was the top exporter of turmeric (US\$ 192 million) followed by Vietnam (US\$ 22.6 million), Indonesia (US\$ 12.8 million) and Burma (US\$ 8.23 million) (via interrnet).

Turmeric powder is about $60-70 \%$ carbohydrates, $6-13 \%$ water, $6-8 \%$ protein, $5-10 \%$ fat, 3-7\% dietary minerals, $3-7 \%$ essential oils, $2-7 \%$ dietary fiber, and $1-6 \%$ curcuminoids (Rajkumari and Sanatombi, 2017). The active golden yellow chemical in turmeric is curcumin $\left(\mathrm{C}_{21} \mathrm{H}_{20} \mathrm{O}_{6}\right)$. The IUPAC name is (1E, 6E)-1,7-Bis(4-hydroxy-3-methoxyphenyl) hepta-1,6diene-3,5-dione. It could be present in enol or keto form (Manolova et al., 2014).

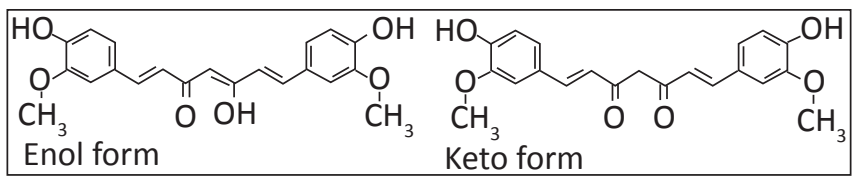

Some research data on turmeric from Tamil Nadu state is presented in Table 1, but much more of such data are needed from other states. It is essential to provide quality data on packages being marketed. The present international market is very quality conscious.

Turmeric has been used in Asia for thousands of years and is a major part of Ayurveda, siddha, traditional Chinese and Unani medicine (Chattopadhyay et al., 2004). It was first used as a dye, and later in folk medicine. It's a potent anti-inflammatory agent and is generally the first thing to be given (mixed in milk) in accidental injuries in India. It is recommended in arthritis and is taken in several forms (TOI, 2019). It is also an antioxidant and may also help to improve symptoms of depression. Other health benefits include prevention of cardiovascular diseases, Alzheimer's and cancer (Prasad and Agarwal, 2011). Nwankwo (2014) reported that he methanolic extract of the plant exhibited significant inhibitory actions against Escherichia coli, Streptococcus, Staphylococcus, Bacillus cereus, Micrococcus, Pseudomonas, Aspergillus and Penicillium at a final concentration of $20 \mathrm{mg} \mathrm{ml}^{-1}$.

It is an important ingredient of curry powder used for vegetable and meat curries in India and abroad. In India it is taken in every meal. It is also used for coloring and flavoring several savory dishes and even some sweet dishes.

\section{Ginger}

Ginger (Zingiber officinale) originated from Islands of Southeast Asia. It is a true cultigen and does not exist in its wild state (Singh, 2011; Ravindran and Nirmal Babu, 2016). The most ancient evidence of its domestication is 


\begin{tabular}{lcccccc}
\hline \multicolumn{6}{l}{ Table 1: Some of the varieties grown in Tamil Nadu, their crop duration and curcumin, oleoresin and essential oil content } \\
\hline Variety name & $\begin{array}{c}\text { Mean yield } \\
\text { (fresh, } \mathrm{t} \mathrm{ha}^{-1} \text { ) }\end{array}$ & $\begin{array}{c}\text { Crop duration } \\
\text { (days) }\end{array}$ & $\begin{array}{c}\text { Dry recovery } \\
\text { (\%) }\end{array}$ & $\begin{array}{c}\text { Curcumin } \\
(\%)\end{array}$ & $\begin{array}{c}\text { Oleoresin } \\
\text { (\%) }\end{array}$ & $\begin{array}{c}\text { Essential } \\
\text { Oil (\%) }\end{array}$ \\
\hline Suvarna & 17.4 & 200 & 20.0 & 4.3 & 13.5 & 7.0 \\
Suguna & 29.3 & 190 & 12.0 & 7.3 & 13.5 & 6.0 \\
Sudarsana & 28.8 & 190 & 12.0 & 5.3 & 15.0 & 7.0 \\
IISR Prabha & 37.5 & 195 & 19.5 & 6.5 & 15.0 & 6.5 \\
IISR Prathibha & 39.1 & 188 & 18.5 & 6.2 & 16.2 & 6.2 \\
Co-1 & 30.0 & 285 & 19.5 & 3.2 & 6.7 & 3.2 \\
Krishna & 9.2 & 240 & 16.4 & 2.8 & 3.8 & 2.0 \\
Sugandham & 15.0 & 210 & 23.3 & 3.1 & 11.0 & 2.7 \\
BSR-1 & 30.7 & 285 & 20.5 & 4.2 & 4.0 & 3.7 \\
Roma & 20.7 & 250 & 31.0 & 9.3 & 13.2 & 4.2 \\
Suroma & 20.0 & 255 & 26.0 & 9.3 & 13.1 & 4.4 \\
Rajendra Sonia & 4.8 & 225 & 18.0 & 8.4 & - & 5.0 \\
Ranga & 29.0 & 250 & 24.8 & 6.3 & 13.5 & 4.4 \\
Rasmi & 31.3 & 240 & 23.0 & 6.4 & 13.4 & 4.4 \\
\hline
\end{tabular}

Source: TNAU Portal //www.icexindia.com/profiles/turmeric_profile.pdf

among the Austronesian peoples where it was exploited since ancient times. Today, India is the largest producer of ginger, and in 2018 it produced 893 thousand tonnes (tt) of rhizomes, followed by China (510 tt), Nigeria (369 tt), Nepal (284 tt), Indonesia (207 tt) and Thailand (168 tt), however, China is number one in exporting crushed/ground ginger (US\$ 30.5 million; $37.2 \%$ of the world total) compared to India's US \$ 12 million; $14.6 \%$ of the world total. In India, about $70 \%$ of the total ginger production is confined to Kerala. Other states that grow ginger are Assam, Andhra Pradesh, Himachal Pradesh, West Bengal and Sikkim.

Ginger grows best in warm and humid climate. It is mainly cultivated in the tropics from sea level to an altitude of 1500 $\mathrm{m}$, both under rainfed and irrigated conditions. Ginger thrives best in well-drained sandy loam or loam red or lateritic soils high in soil fertility. It is planted in March to June and is a 7-8 month crop. It requires high humidity for the first 6 months of growth and dry weather with a temperature of $28^{\circ}$ to $35^{\circ} \mathrm{C}$ for about a month before harvesting. Harvesting is done by digging with a spade or pick-axe.

Dried ginger contains $5.02-5.82 \%$ protein, $4.97-5.61 \%$ crude fiber, $0.76-0.90$ fat, $3.38-3.66 \%$ ash, $0.81 \mathrm{mg} 100 \mathrm{~g}^{-1}$ $\beta$-carotene and $3.83 \mathrm{mg} 100 \mathrm{~g}^{-1}$ ascorbic acid and $69.21 \mathrm{mg}$ $100 \mathrm{~g}^{-1}$ polyphenol (Sangwan et al., 2014). The active ingredient in ginger is gingerol $\left(\mathrm{C}_{17} \mathrm{H}_{26} \mathrm{O}_{4}\right)[(\mathrm{S})$-5-Hydroxy-1-(4hydroxy-3-methoxyphenyl)-3-decanone] with the following formula.<smiles>CCCCC(O)CC(=O)CCc1ccc(O)c(OC)c1</smiles>

Gingerol is a phenol phytochemical compound found in fresh ginger that activates spice receptors on the tongue. It is a relative of alkaloids capscine and piperine .

Ginger rhizomes and the leaves are used to flavor food or eaten directly. Ginger is used in India in making curry paste and dips (chutney). Ginger appears to be highly effective against nausea. It has a long history of use as a sea sickness remedy, and there is some evidence that it may be as effective as prescription medication. Ginger can help in overcoming indigestion, has anti-inflammatory effects and can help with osteoarthritis. Ginger may drastically lower blood sugars and improve heart disease risk factors. It can also reduce the risk of cancer and also helps in overcoming depression (D'costa, 2019).

\section{Isabgol / Psyllium}

Isabgol (Plantago ovata) also known as Aspaghol (Persian 'asp' meaning horse and 'gul' meaning flower, the word thus means horse flower) is an annual herb of Iranian origin, but India is now a major producer and exporter. The genus Plantago contains over 200 species. P. ovata produced in India is known as white or blonde psyllium, while $P$. psyllium commercially known as black, French, or Spanish psyllium is produced in several European countries. India is the largest producer in the world and has monopoly in its trade. In India it is grown in North Gujarat and adjoining parts of Western Rajasthan and Madhya Pradesh. However, the crop is spreading in non-traditional parts of the country such as Punjab, Haryana, Uttar Pradesh and Karnataka. It is a cool and dry season (rabi) crop. It requires an annual rainfall 500-1250 
$\mathrm{mm}$. Since, the papery seed husk can absorb water many times than its own weight and swell and drop off due to increase in weight, hence unseasonal rain or, even high dew deposition during the crop maturity is the major deterrent factor in isabgol cultivation and can cause total loss of the yield. Thus, regions receiving winter rains are not suitable for isabgol cultivation. The temperature requirement for maximum seed germination is $20-25^{\circ} \mathrm{C}$, whereas, at the time of maturity it requires a temperature of $30-35^{\circ} \mathrm{C}$. Plants flower about 60 days after planting. The seeds are enclosed in capsules that open at maturity. Both seeds and husk are used.

Isabgol/Psyllium is a proven bowel regulator (Cheng et al., 2019). It is mainly used as a viscous, soluble dietary fiber that is not absorbed by the small intestine. The purely mechanical action of psyllium mucilage is to absorb excess water while stimulating normal bowel elimination. It also lowers blood cholesterol (Olson et al., 1997) and thus is useful in reducing the risk of coronary heart disease. Psyllium husk may also reduce the risk of type 2 diabetes.

\section{Senna}

Senna (Cassia) is native to Africa and is grown several countries with semi-dry climate. It has been grown in the Egypt since long and is now grown throughout semi-arid tropics and even in some temperate region countries. There are about 300 species of which about 50 species of Senna are in cultivation. The most common cultivated species are: Cassia aculeata, $C$. augustifolia and C. alexandrina (in Egypt). India has the largest area (about 0.1 million hectares) under senna cultivation mostly in the states of Tamil Nadu, Gujarat and Rajasthan. India is the largest exporter of senna. Both leaves and seeds are exported and used after grinding and forming tablets. The total annual production of senna herbage in India is estimated to be around 8600 tonnes. The international market receives leaves and pods of Alexandrian senna obtained from the North African countries in substantial quantities, accounting for about $25 \%$ of the international trade

Senna grows well in medium to high rainfall (700-1500 mm) areas with $25-30^{\circ} \mathrm{C}$ temperatures. It grows well on loam soils of $\mathrm{pH}$ 5-7.5. It is a kharif season crop.

Indian senna (Cassia angustifolia) contains flavonoids, pinnitolos (polyols), acidic polysaccharides, and mineral substances. It also contains two types of glucosides known as sennoside $A$ and $B$, and other compounds including myricyl alcohol, anthraquinone derivatives, galactose, arabinose, rhamnose, and galacturonic acid, chrysophanic acid, salicylic acid, resin, mannitol, and trace amounts of volatile oil (Naz et al., 2019). Senna is mostly used as a laxative for the treatment of constipation (Wald, 2016; Izzy et al., 2016), but is also used in diarrhea and dysentery.

\section{Discussion and Agenda for Action}

Since most agricultural research has been with cereals, where the main quality traits were boldness and lustre in grains other than rice, while in rice it was fineness and length of grain, which are only the physical characters. There has been no attempt on determining the protein content even in wheat, a major consideration in US and Canadian wheat markets. The crops mentioned in this paper are marketed for their active chemical constituents, which are responsible for their health and culinary benefits. Therefore, declaration of the content of these chemicals is a prerequisite for each lot sold in the international market. A beginning of this has to be made at the farm gate and there is a need for such analyses at that very point.

Therefore, breeding of better quality varieties of such crops requires strong science (chemistry) base and the agricultural scientists need to work in unison with chemists. At present there are two institutes in India responsible for this. One is the Indian Institute of Spices Research (IISR) at Kozhikode, Kerala under the control of the Indian Council of Agricultural Research (ICAR), New Delhi of the Ministry of Agriculture \& Farmers Welfare, while the other is Central Institute of Medicinal and Aromatic Plants, Lucknow under the control of Council of Scientific \& Industrial Research of the Ministry of Science and Industry. Since two ministries are involved, coordination is a difficult job. ICAR has a separate institute/ directorate for each cereal crop and traditional crop, such as, cotton, sugarcane and potato. There is a need for a separate institute for herbal crops also with well-equipped analytical chemistry laboratories having well trained staff, where a farmer or a businessman can get his samples analyzed for a small reasonably fee at a short interval of time. Such laboratories will also create many jobs for analytical organic chemists.

In agriculture research, the only time the need for labs was felt with the introduction of soil testing laboratories all over the country and there was a flurry of lab to land. It is time to talk also of land to lab, required in the context of the crops discussed in this paper.

\section{Conclusion}

For the crops under reference there is an immediate need for marketing research to familiarize people of the health and culinary advantages of these crops. At the moment this job is being done by importing agencies of a country. We as an exporting country also owe some responsibility in this direction. Needless to mention that people in advanced countries have just become aware of the health benefits of these crops and would like to have more information. As regards health benefits, there is an urgent need of conducting randomized trials for bringing out the evidence of health benefits of these medicines and Ministry of AYUSH has the major responsibility. Sooner it is done better it is.

\section{References}

Attwood, D.W., 2005. Big is ugly? How large-scale institutions 
prevent famines in Western India. World Development 33, 2067-2083.

Bhatia, B.M., 1985. Famines in India: A study in some aspects of the economic history of India with special reference to food problem, Konark Publishers, Delhi.

Chattopadhyay, I., Kaushik, B., Uday, B., Ranajit, K.B., 2004. Turmeric and curcumin: biological actions and medicinal applications. Current Science 87(1), 44-53.

Cheng, J., Tennila, J., Stenman, L., Ibarra, A., Kumar, M., Gupta, K.K., Sharma, S.S., Sen, D., Garg, S., Penurkar, M., Kumar, S., Ouwehand, A.C., 2019. Influence of lactitol and psyllium on bowel function in constipated Indian volunteers: A randomized, controlled trial. Nutrients 11, 1130. (doi: 10.3390/nu11051130).

Currey, B., Hugo, G., 1984. Famine as a geographical phenomenon. Springer, Netherlands.

Das, A., 2011. Farmers' suicide in India: implications for public mental health. International Journal of Social Psychiatry 57(1), 21-29.

D'costa, M., 2019. Health benefits of ginger. Times of India, July 8, 2019.

Drèze, J., 1988. Famine prevention in India. Development Economics Paper No. 3, London School of Economics, London.

Dongre, A.R., Deshmukh, P.R., 2012. Farmers' suicides in the Vidarbha region of Maharashtra, India: a qualitative exploration of their causes. Journal of Injury and Violence Research 4(1), 2-6.

Izzy, M., Malieckal, A., Little, E., Anand, S., 2016. Review of efficacy and safety of laxatives use in geriatrics. World Journal of Gastrointestinal Pharmacology and Therapeutics 7(2), 334-342.

Keay, J., 2001. India: A history. Grove Press, New York.

Kaul, J., Dass, S., Manivannan, A., Singode, A., Sekhar, J.C., Chikkappa, G.K., Om, P., 2010. Maize hybrid and composite varieties released in India (1961-2010), Director Directorate of Maize Research, Pusa Campus, New Delhi.

Kumara Charyulu, D., Bantilan, M.C.S., Nedumaran, S., Deb, U.K., 2011. Development and diffusion of improved sorghum cultivars in India: Impact on growth and variability in yield. Open Access Repository, International Crops Research Institute for Semi-arid Tropics, Patancheru, A.P., India.

Manolova, Y., Deneva, V., Antonov, L., Drakalska, E., Momekova, D., Lambov, N., 2014. The effect of the water on the curcumin tautomerism: A quantitative approach. Spectrochimica Acta. Part A, Molecular and Biomolecular Spectroscopy 132, 815-820. DOI: 10.1016/j.saa.2014.05.096.
Naz, H., Nawaz, H., Hanif, M.A., Ayub, M.A., Khatun, S., 2019. Indian Senna, Chapter 33. In: Haq, M.H., Khan, N.M., Byrne, H. (Eds.), Medicinal Plants of South Asia, Elsevier, USA, 439-449.

Nwankwo, C.S., 2014. Nutritional composition of turmeric (Curcuma longa) and its antimicrobial properties. Proceedings International Journal of Scientific and Engineering Research 5(10), 1085-1089.

Olson, B.H., Anderson, S.M., Becker, M.P., Anderson, J.W., Hunninghake, D.B., Jenkins, D.J., LaRosa, J.C., Rippe, J.M., Roberts, D.C., Stoy, D.B., Summerbell, C.D., Truswell, A.S., Wolever, T.M., Morris, D.H., Fulgoni, V.L., 1997. Psyllium-enriched cereals lower blood total cholesterol and LDL cholesterol, but not HDL cholesterol, in hypercholesterolemic adults: results of a metaanalysis. Journal of Nutrition 127(10), 1973-1980.

Prasad, S., Aggarwal, B.B., 2011. Turmeric, the golden spice, Chapter 13. In: Iris, F.F., Benzie, S., Wachtel-Galor, (Eds.), Herbal Medicine, Biomolecular and Clinical Aspects, $2^{\text {nd }}$ edition, . CRC Press, Boca Raton, FL, USA.

Rajkumari, S., Sanatombi, K., 2017. Nutritional value, phytochemical composition, and biological activities of edible Curcuma species: A review. International Journal of Food Properties 20(3), S2668-S2687.

Ravindran, J., Nirmal Babu, K., 2016. Ginger: The Genus Zingiber. CRC Press, Boca Raton, FL, USA.

Roy, P.C., 1889. The Mahabharata of Krishna-Dwaipayana Vyas- Krishna Parva (Translation), Bharata Press, Calcutta.

Sangwan, A., Kawatra, A., Sehgal, S., 2014. Nutritional composition of ginger powder prepared using various drying methods. Journal of Food Science and Technology 51(9), 2260-2262.

Siddiq, E.A., Vemireddy, L.R., Nagaraju, J., 2012. Basmati rices: genetics, breeding and trade. Agricultural Research 1, 25-36.

Singh, R.J., 2011. Genetic resources, chromosome engineering, and crop improvement series medicinal plants volume 6, CRC Press, Boca Raton, FL, USA.

Swaminathan, M.S., 2013. Genesis of yield and growth of yield evolution in India: Lessons for shaping our agricultural destiny. Agricultural Research 2(3), 183-188.

TOI, 2019. Ten healthy turmeric recipes for arthritis. Times of India, August 6, 2019.

Wald, A., 2016. Constipation:advances in diagnosis and treatment. Journal of American Medical Association 315(2), 185-191.

Walsh, J.E., 2006. A brief history of India. Facts on File, New York. 